\title{
Grotius on Reprisal
}

\author{
Randall Lesaffer \\ KU Leuven, Belgium \\ Tilburg University, The Netherlands \\ randall.lesaffer@kuleuven.be
}

\begin{abstract}
In neither of his two major forays into the laws of war and peace - De iure praedae or De iure belli ac pacis - did Hugo Grotius discuss the legal institutions of reprisal whether special or general - or privateering in their own right. His profoundly novel reading of the just war doctrine in the context of his theory of natural rights, however, gave powerful legitimisation to the practices of special reprisals, as well as of privateering in times of war and of peace.
\end{abstract}

\section{Keywords}

\section{Special Reprisal, General Reprisal, Privateering}

In the final weeks of the year 1664, the British King Charles II (166o-1685) issued general reprisals against the Republic of the United Provinces, ordering the seizure of all Dutch ships in England and on the high seas. Although this was typically a war-time measure, the king refrained from declaring war, or giving full execution to the order. While almost thirty Dutch ships had been effectively seized by late February 1665, no case was yet brought before the admiralty to declare them good prize and confiscate them, nor were letters of marque issued to privateers allowing them to prey on Dutch merchants or fishermen on the seas. Only after the measures failed to force any concession out of the Dutch did Charles II issue further declarations against the Republic of the Northern Netherlands. These declarations from 2 and 14 March 1665 entailed a full execution of the order, allowed for the High Lord of the Admiralty to 
issue letters of marque, and imposed measures against neutral trade with the Republic. Even the final declaration was not styled as a formal declaration of war; it labelled the Dutch as 'aggressors' but refrained from declaring full war. To the Dutch, however, it was tantamount to a declaration of war. They judged that they had no choice but to alert their allies and neutral states that the Republic would act against neutral trade with Britain, while third states as well considered the laws and customs concerning neutral trade now to be in operation, as they were in times of war. Naval action in the late spring took away all doubt and brought the two states finally from the misty zone between peace and war into that of open rupture. ${ }^{1}$

These events from the turn of 1665 marked the final descent of the British Monarchy and the Dutch Republic into war, after a drawn-out period of escalation. Ever since the end of the First Anglo-Dutch War (1652-1654) in the days of the British Commonwealth, renewed war had never been far from the mind of some factions in the British power elite. The Peace of Westminster of 5 April 1654 left many dissatisfied as they opined that the British government had not exploited its ascendancy in the war sufficiently to curb Dutch control over the cargo trade in Europe. ${ }^{2}$ The Stuart restoration of 166 o did not alter this. In the mid-166os, tensions rose as a fierce competition about the slave trade on the coast of West Africa took off between the recently created merchant company of the Royal Adventurers and the Dutch West India Company. An increasingly vocal coalition of merchants, former privateers, and young courtiers, led by the king's brother and successor, James (1633-1701), Duke of York and Lord High Admiral, pressured a reluctant king towards war. In the spring of 1664, an expedition of the Royal Adventurers, supported by the navy, ravished the Dutch positions in West Africa. The Dutch government under Grand Pensionary John de Witt (1625-1672) retaliated by sending a navy squadron from the Mediterranean under Michiel de Ruyter (1607-1676) to African waters, which turned the tables on the British. This latter action caused Charles iI to declare general reprisals. ${ }^{3}$

1 Order for general reprisals against the Dutch, in Documents Relating to Law and Custom of the Sea, ed. by R.G. Marsden, vol. II (London: Navy Records Society, 1916), pp. 48-9; Declaration by Charles II against the Dutch Republic of 2 March 1665; Lieuwe van Aitzema, Saken van Staet en Oorlogh, in, ende omtrent de, Vereenigde Nederlanden, vol. V (The Hague: Johan Vreet, Johan Tongerloo, and Japser Dozz, 1670), pp. 351-71. Also see Matthew Hale, The History of the Pleas of the Crown, vol. I (Philadelphia: Robert H. Small, 1847), p. 162.

2 In The Consolidated Treaty Series, ed. by Clive Parry, vol. III (231 vols., Dobbs Ferry: Oceana Publications, 1969-1981), p. 225 (hereinafter CTs).

3 J.R. Jones, The Anglo-Dutch Wars of the Seventeenth Century (London and New York: Longman, 1996), pp. 145-56; Herbert H. Rowen, John de Witt, Grand Pensionary of Holland, 1625-1672 (Princeton: Princeton University Press, 1978), pp. 460-4 and 574-5. 
Although the Second Anglo-Dutch War saw spectacular naval actions, most famously the Dutch raid on Medway in July 1667, these were just sporadic events which interlaced the constant preying on merchant shipping by the navies and scores of privateers from both sides. The Dutch coup at Medway did push Charles II to accept peace at Breda, ${ }^{4}$ but the huge damage done by Dutch privateers to British shipping went a long way in sapping the support base for the war in London. The Anglo-Dutch Wars of the mid-seventeenth century (1652-1654, 1665-1667, and 1672-1674) marked a highpoint in the history of privateering on the seas of Europe and beyond. ${ }^{5}$

Scholars have often searched for the roots of privateering in the late-medieval institution of special reprisal. ${ }^{6}$ Although there is some justification in this, these are two distinct legal institutions. Privateering was a wartime measure under which private ship owners received a commission from the sovereign to prey on shipping belonging to the enemy state and to enemy subjects. They thus acted under the jura belli, the predecessor of the modern laws of war, which allowed to seize and plunder all enemy property. ${ }^{7}$ A special reprisal was a peacetime measure whereby a private person received permission from his sovereign, through a letter of reprisal, to seek compensation for damage suffered from a foreign person against the property of any subject of the sovereign of the latter. The institution had its roots in commercial practices. Often, the lessee who received a right of reprisal would execute it against foreign subjects present in the lands of his own prince or government and would thus be able to enlist the support of his own ruler's officials. But during the Late Middle Ages, it also became common for a letter of reprisal - in this case, often referred to as a letter of marque - to allow forcible actions outside the jurisdiction of the rulers, as on the high seas. Between the thirteenth and fifteenth century, the practice of special reprisals was increasingly regulated. A standard demand was that the lessee had to prove that he had exhausted judicial means in the country of the perpetrator to claim redress and that he had met with a denial of justice, or with a manifestly unjust outcome. It was also customary

4 Peace Treaty of Breda of 31 July 1667 , 10 CTS 231.

5 Virginia West Lunsford, Piracy and Privateering in the Golden Age Netherlands (Basingstoke: Palgrave Macmillan, 2005), pp. 9-26.

6 E.g. Wilhelm G. Grewe, The Epochs of International Law (Berlin: Walter de Gruyter, 20oo), pp. 201-3.

7 Peter Haggenmacher, 'On the Doctrinal Origins of Ius in Bello: From the Rights of War to the Laws of War', in Universality and Continuity in International Law, ed. by Thilo Marauhn and Heinhard Steiger (The Hague: Eleven, 2011), pp. 325-58. 
for governments first to intervene with their counterparts and try to obtain a settlement through amicable means. ${ }^{8}$

Nevertheless, there are terminological and historical connections between special reprisal and privateering. In addition to the use of the term 'letter of marque' for a privateering commissions, the two institutions are joined at the hip through the term 'general reprisal'. This phrase is used to indicate a general order by a government to seize all the property from another state and its subjects. The fundamental difference between special and general reprisal lies in the fact that special reprisals limit seizure of foreign property to the extent of the damage suffered by a specific person and the costs involved in their recuperation, while there are no such limitations for general reprisals.

Whereas writers of the law of nations from the eighteenth and nineteenth centuries would generally restrict the use of general reprisals to situations of open and declared war, or consider it an act of war, states at times did resort to general reprisals, and under this heading, commissioned privateers, without calling for open war. ${ }^{9}$ Although this remained controversial in both practice and legal scholarship, it opened a grey zone between war and peace which was further widened and exploited during the nineteenth century with the modern form of forcible reprisal. This institution from modern international law implies the use of limited force in time of peace by a state in retribution against a violation of its rights or those of its subjects by another state. ${ }^{10}$ General reprisal during peace

8 René de Mas Latrie, Du droit de marque ou droit de représailles au Moyen-Age suivi de pieces justificatives (2nd edn., Paris: Baur 1875); Peter Haggenmacher, 'Lancêtre de la protection diplomatique: les représailles de l'ancien droit (XIIe-XVIIIe siècles)', Relations internationales, 143 (2010), 7-12; Ernest Nys, Les origines du droit international (Brussels/ Paris: Alfred Castaigne/Thorin \& Fils 1894), pp. 63-7; Theodore T. Richard, 'Reconsidering the Letter of Marque: Utilizing Private Security Provider against Piracy', Public Contract Law Journal 39 (2010), 411-64, at pp. 412-26; Hans W. Spiegel, 'Origin and Development of Denial of Justice', in International Law in the Twentieth Century, ed. by Leo Gross (New York: Appleton-Century-Crofts, s.d.), pp. 518-36; Johan Hendrik Willem Verzijl, International Law in Historical Perspective, vol. viII (Leiden: Sijthoff, 1976), pp. 37-9.

$9 \quad$ E.g. August Wilhelm Heffter, Das europäische Völkerrecht des Gegenwart, 3rd edn (Berlin: Schroeder, 1855), pp. 219-20; Georg Friedrich von Martens, An Essay on Privateers, Captures, and Particularly on Recaptures, according to the Laws, Treaties, and Usages of the Maritime Powers of Europe (London: E. and R. Brooks and J. Rider 1801), p. 1. See Grewe, Epochs, pp. 367-70.

10 Ian Brownlie, International Law and the Use of Force by States (Oxford: Clarendon Press, 1963), pp. 26-46; Stephen C. Neff, War and the Law of Nations. A General History (Cambridge: Cambridge University Press, 2005), pp. 225-39. 
is the historical antecedent of modern reprisal as a measure short of war, whose emergence roughly coincides with the demise and final repression of privateering. ${ }^{11}$

Special reprisal was subject to controversy in late-medieval legal scholarship, as writers objected to the idea of collective liability, a notion unknown to Roman law and inconsistent with the Christian moral theology of individual sin, penance, and divine retribution. Whereas the institution had its roots in commercial practices, its major theoretical elaboration by late-medieval civilians - most famously those of Bartolus of Sassoferrato (1313/14-1357) and his follower Giovanni da Legnano (d.1383) - occurred in the context of discussions of just war. ${ }^{12}$ This allowed for its defence as a measure of common defence and enforcement of rights. ${ }^{13}$

In neither of his two major forays into the laws of war and peace-making De iure praedae of 1604-1606 and De iure belli ac pacis of 1625 - did Hugo Grotius (1583-1645) devote much attention to reprisal. De iure praedae only contains a few brief references to the practice of reprisal. ${ }^{14}$ These are rather in the nature of corroborating Grotius's exposition of just war than an argument on the institution of reprisal itself. Grotius's fuller systematisation of the laws of war and peace-making from 1625 includes a brief exposition of the subject in the second chapter of the third book. ${ }^{15}$ Nevertheless, these works hold relevance to the doctrinal understanding of reprisals - whether special or general and privateering as Grotius's system provided powerful support for fixing these practices within the logic of just war and cloaking them in the language of natural justice.

11 Jan Martin Lemnitzer, Power, Law and the End of Privateering (Bastingstoke: Palgrave Macmillan, 2014).

Bartolus da Sassoferrato, Tractatus Represaliarum (1354), in Consiliorum Bartoli Libri Duo (Lyon: Guido Blasius, 1555), ff. 125r-131r.; Giovanni da Legnano, Tractatus de Bello, de Represailiis, et de Duello (c. 136o), ed. by Thomas Erskine Holland (The Classics of International Law; Oxford: Oxford University Press, 1917); Jacob Giltaij, 'Roman Law and the Causa Legitima for Reprisal in Bartolus', Fundamina 20 (2014), 349-56.

13 See the paper by Philippine van den Brande in this issue of Grotiana.

14 Hugo Grotius, De iure praedae commentarius, transl. by Gwladys L. Williams (The Classics of International Law; Oxford/London: Clarendon Press/Geoffrey Cumberledge), 1.8, f. 48' and 5 o; 1.10, f. $58 ; 1.13$, f. 139, hereinafter IPC.

Hugo Grotius, De iure belli ac pacis libri tres (text of 1646), transl. by Francis W. Kelsey (The Classics of International Law; Oxford/London: Clarendon Press/Humphrey Milford, 1925), III.2, hereinafter $I B P$. 


\section{De Iure Praedae}

In late 1604, Grotius was approached from within the board of directors of the United East India Company (voc) to write and publish a defence of the capture of the Portuguese carrack Santa Catarina. This ship and its rich cargo had been taken by Jacob van Heemskerk (1567-1607), admiral for the United Amsterdam Company, in the Strait of Singapore in February 1603. The carrack was brought to Amsterdam, where in September 1604 the court of admiralty declared it good prize and granted it to Van Heemskerk, his captains and crew, and the United Amsterdam Company, or rather its legal successor, the voc. The verdict, which did not entail a very clear or elaborate legal justification for the decision, settled the case in formal terms but did not exhaust debate on these events. ${ }^{16}$ The capture and case had stirred a controversy over the moral, political, and commercial wisdom of bringing the war against the Iberian Monarchy through the instances of the voc to the East Indies. ${ }^{17}$

The main thrust of Grotius's argument for the case of Van Heemskerk and the voc was that the Santa Catarina and its cargo were good prize in a just war. With this, Grotius appealed to the longstanding doctrine of bellum iustum, which had seen its first elaboration in the writings of twelfth-century canonists, chiefly Gratian (d. c. 116o) and reached its classical form through the endeavours of the theologian Thomas Aquinas (c. 1225-1274). Under the doctrine, war was conceptualised as the armed enforcement of a right which has been violated by the enemy. It was an instrument of self-help for sovereigns to seek redress for wrongful action (iniuria), absent a higher authority to turn to. ${ }^{18}$

Grotius first set out to write what ultimately became the eleventh chapter of his massive essay. In it, he offered a detailed survey of the many misdeeds of the Portuguese in Europe and the Indies against the Dutch Republic and its subjects, going back to the time when the Spanish king had seized the Portuguese crown in the early 1580s. With this, Grotius seemingly fell in line with the then standard discourse which was typical for the justification of war under the classical just war doctrine from official declarations and manifestos

16 For the text of the verdict of 9 September 1604 see, Hugo Grotius, Commentary on the Law of Prize and Booty, ed. by Martine J. Van Ittersum (Natural Law and Enlightenment Classics; Indianapolis: Liberty Fund, 2006), pp. 510-4.

17 Martine J. Van Ittersum, Profit and Principle. Hugo Grotius, Natural Rights Theories and the Rise of the Dutch Power in the East Indies (1595-1615) (Leiden and Boston: Brill, 2006), pp. 1-43.

18 Peter Haggenmacher, Grotius et la doctrine de la guerre juste (Paris: Presses Universitaires de France, 1983); Frederick H. Russell, The Just War in the Middle Ages (Cambridge: Cambridge University Press, 1975). 
of war. He endeavoured to show that the Dutch had just cause in the misdeeds of the Portuguese while their number, longevity, and excess indicated that war had been absolutely necessary. In this manner, Grotius proved that Dutch warring against the Portuguese, or the Iberian monarchy, accorded with two of the five key conditions for a war to be just: just cause and necessity. ${ }^{19}$

Grotius, however, could not stop there as he had a harder nut to crack in order to prove that the capture of the Santa Catarina also corresponded to the three other conditions of just war. Thomas Aquinas had famously listed three conditions for the justice of war. Firstly, a war had to be waged by or under the authority of a sovereign (causa efficiens). Secondly, there needed to be a just cause (causa materialis) which consisted in seeking redress for a prior wrongdoing by the enemy. Thirdly, the just belligerent had to act with righteous intention, which came down to a mental disposition to do justice rather than to seek gain or revenge (causa finalis). ${ }^{20}$ This all logically implied that the war was a last resort (necessity) and that belligerent action had to be proportional to the wrong inflicted and the redress sought (causa formalis). In the case at hand, the prize had been taken by a fleet commandeered by a private company, the United Amsterdam Company, while it stood in no proportion to the damage the Portuguese had directly caused to Van Heemskerk and his crews. By consequence, Grotius had to expand his argument by proving that 1) the prize was not disproportional, 2) that it could be taken from the owners of the Santa Catarina for misdeeds committed by other Portuguese, 3) that Van Heemskerk and co. held lawful agency to execute the 'just war', and 4) gain title to the prize for themselves. From the perspective of the opponents of the capture within and without the Republic, Grotius's brief was to justify a case of high sea robbery.

The young polymath set out to do this by adding a lengthy, ten-chapter systematisation of the doctrine of just war in front of his historical argumentation. He then concluded his essay by applying his novel theory of just war to the case in two final chapters. In order to achieve his purpose, Grotius reassembled the classical just war doctrine by imbedding it into the framework of a novel theory of law and justice and thus put in into a different key.

19 Randall Lesaffer, 'Between Faith and Empire: The Justification of the Spanish Intervention in the French Wars of Religion in the 159os', in International Law and Empire. Historical Explorations, ed. by Martti Koskenniemi, Walter Rech, and Manuel Jiménez Fonseca (Oxford: Oxford University Press, 2017), pp. 101-22.

$20 \quad$ IIaIIae 40.1; English translation in Aquinas: Political Writings, ed. by R.W. Dyson (Cambridge Texts in the History of Political Thought; Cambridge: Cambridge University Press, 2002), p. 240. 
The classical just war doctrine of the twelfth and thirteenth centuries was the product of canon lawyers and theologians. Their primary concern was to question the effects of waging or participating in war on an individual's eternal life. In the words of Aquinas, 'whether it is always sin to wage war'. ${ }^{21}$ Grotius loosened the question of the justice of war from this moral-theological context by placing it squarely in the ambit of natural law and emancipating natural law as a body of law from its traditional amalgamation with divine law and canon law. This did not amount to a complete secularisation of natural law as Grotius insisted on the origins of creation and natural law in divine will and hence considered transgressions against natural law to be sins. ${ }^{22}$ However, Grotius did liberate the pursuit and enforcement of natural justice under the logic of natural law from theological considerations by distinguishing it as an autonomous category of law, distinct from arbitrary divine law, such as the Decalogue or the Law of the Gospel. Whereas both laws, natural law and divine law, derived from divine will, they had different epistemological sources. Whereas natural law followed from creation and was intelligible to all human beings, arbitrary divine law followed from later divine interference and was only known through revelation. ${ }^{23}$

This separation allowed Grotius to perceive of natural law as a set of enforceable, individual or subjective rights. ${ }^{24}$ The pursuit of justice under natural law was a matter of corrective justice (iustitia compensatrix). This sanctioned the one-sided enforcement of his rights by an individual against their violator, without regard for the general welfare (bonum commune) and general justice within the commonwealth. By consequence, in case of need, the rights

$21 \quad$ IIaIIae 40.1, p. 239.

22 Grotius, IPC, I, f. 4' and 14; Haggenmacher, Grotius, pp. 471 and 591-4; Merio Scattola, 'Law, War and Method in the Commentary on the Law of Prize by Hugo Grotius', Grotiana N.S. 6/8 (2005-7), 79-103, at p. 97; Mark Somos, 'Secularization in De Iure Praedae: from Bible Criticism to International Law', Grotiana N.S. 26-8 (2005-7), 147-91; Benjamin Straumann, Roman Law in the State of Nature. The Classical Foundations of Hugo Grotius' Natural Law (Cambridge: Cambridge University Press, 2015), pp. 39-41; Francesco Todescan, 'Sequuntur Dogmatica De Iure Praedae: Law and Theology in Grotius's Use of Sources in De Iure Praedae', Grotiana N.S. 26-8 (2005-7), 281-309.

23 Christoph A. Stumpf, The Grotian Theology of International Law. Hugo Grotius and the Moral Foundations of International Relations (Berlin: Walter de Gruyter, 2006).

24 Peter Haggenmacher, 'Droits subjectifs et système juridique chez Grotius', in Politique, droit et théologie chez Bodin, Grotius et Hobbes, ed. by Luc Foisneau (Paris: Editions Kimé, 1997), pp. 73-130, at pp. 112-3; H. Nellen, 'Minimal Religion, Deism and Socinianism: on Grotius's Motives for Writing De Veritate', Grotiana N.S. 33 (2012), 25-57; idem, 'Hugo Grotius on Religion as a Motive for Waging War', in Recht, Konfession und Verfassung im 17. Jahrhundert. West- und mitteleuropäische Entwicklungen, ed. by Robert von Friedeburg and Matthias Schmoeckel (Berlin: Dunker \& Humblot, 2015), pp. 261-8. 
of self-defence and property (Laws I and II), which were based on the animal instinct of self-preservation, superseded the concomitant obligations not to cause injury to another or seize his property (Laws III and IV), which were based on man's reasonable and social nature. ${ }^{25}$ Hereby, Grotius dispensed with the more communitarian dimensions of the condition of righteous intention and reduced the material justification of war to the mere enforcement and restoration of one's individual rights. Distributive justice (iustitia proportionalis) he relayed to the divine laws; it was a matter of morality (honestum) and not natural law (iustum). ${ }^{26}$

The causa materialis of seeking redress for injury was thus placed centre-stage in Grotius's articulation of the just war doctrine to the detriment of the causa finalis. Or put differently, the latter was for all ends and purposes reduced and collapsed into the material cause. Grotius elaborated on the different rights which one could enforce through war through an appeal to the novel structuring of Roman law which humanist scholars such as Hugo Donellus (1527-1591) had introduced on the basis of the Institutes of Justinian. This divided civil law into persons, rights to things (property), rights against other persons (obligations), and actions (remedies). This classification returned with Grotius in the right to self-defence, the right to recover or seek compensation for property, and the right to enforce obligations, whether arising from contract or wrongdoing (delict). To this, Grotius added the right to punish the perpetrators of a wrongdoing, by causing damage or seeking retribution beyond the extent of the injury. ${ }^{27}$

This novel theory of just war created a platform for Grotius to argue that the many injuries which the Portuguese had caused the Dutch Republic and its subjects created a right to recover their property and seek compensation for the damage through a just war. He, however, needed to take the argument further.

Firstly, Grotius had to prove that the capture of a huge prize such as the Santa Catarina fell within the confines of enacting justice. For this purpose, the young writer delved into the question of how war had to be pursued (causa formalis) with regards to enemy property. According to Grotius, all enemy property was liable for seizure in a just war. For this he listed different justifications.

\footnotetext{
25 Grotius, IPC, viII, f. 46 .

26 Grotius, IPC, II, f. 8.

27 Grotius, IPC, viI, ff. 29'-3o. Benjamin Straumann, 'Ancient Caesarian Lawyers in a State of Nature. Roman Tradition and Natural Rights in Hugo Grotius's De Iure Praedae', Political Theory, 34 (2006), 328-50, at p. 339; idem, 'Is Modern Liberty Ancient? Roman Remedies and Natural Rights in Hugo Grotius' Early Work on Natural Law', Law and History Review, 27 (2009), 55-85; idem, Roman Law, pp. 170-206.
} 
In first order, the just belligerent has a right to take away all the goods and possessions of the enemy prince and its subjects as these were all instruments of war and aided the unjust belligerent to pursue his illegitimate resistance. Such seizure was, however, of limited duration as it was a temporary wartime measure, a sequestration which suspended enemy tenure and use of the property rather than a confiscation with transferred title of ownership. While this justified any Dutch captures during war, it did not allow for their permanent attribution to the Dutch Republic or its subjects. This forced Grotius to deal with the question to what proportion of enemy goods the just belligerents could lay a claim of ownership. In order not to jeopardise the Voc 's and their agents' title to the Santa Catarina and its cargo, Grotius needed to deal with the demand of proportionality between redress and prize in such a manner that it allowed for captures which were indeterminate to the point of being limitless, and thus de facto disproportional. For this, Grotius could revert to traditional understandings of just war which allowed the just belligerent to recover his property and to seek compensation for lost property and damage inflicted by the enemy's wrongdoing before the war. On top of this, the just belligerent could also enact compensation for all costs and damages pursuant to the war itself, which was unjust on the side of the enemy. This opened a door to virtually limitless prize-taking. To these traditional points, Grotius added a right to inflict punitive damages beyond the measure of compensation. The right of punishment thus gave another justification for effectively dispensing with the demand of proportionality. ${ }^{28}$

Secondly, Grotius needed to make the case that the Santa Catarina was a lawful prize in a war against the Iberian monarchy by arguing that all property belonging to the Spanish king or its subjects was liable for capture. Grotius achieved this by making a double claim: he held that the state was accountable for the actions of its officials and subjects while subjects were also accountable for the actions of their state. For this, he based himself on his theory of social contract. According to Grotius, states emerged from social contract whereby individuals transferred their power to enforce their natural rights to the state. Collective responsibility thus did not derive from natural law, but was consequential to the establishment of states and derived from human-made law, municipal law (ius civile) and the secondary law of nations. ${ }^{29}$

The transfer of natural rights enforcement to the state made the latter responsible for the actions of its citizens in relation to other states or their citizens. This responsibility implied that the state was held first and foremost to ensure justice

\footnotetext{
28 Grotius, IPC, IV, ff. $20^{\prime}-23$.

29 Neff, War and the Law of Nations, pp. 100-1.
} 
to the victim of an injury committed by one of its citizens. In case the state had commanded the injury, or failed to do justice - through denial of justice - , it incurred direct liability for the subject's wrongdoing. In reverse, subjects were likewise to be held collectively accountable for the actions of their state, its officials, and indirectly through the state, their fellow citizens. ${ }^{30}$ Grotius's logic gave a new foundation to a similar conception of collective accountability on which the institution of special reprisal rested. He was aware of this. At this exact point in his treatise he made a direct reference to the Roman practice of pigneratio, or seizure of pledges, which was commonly considered an antecedent of reprisal. ${ }^{31}$ Somewhat later, he drew another parallel between seizure of enemy property in retribution for a state's actions during war and reprisal where he stated that collective accountability did extend to property, but not to life. ${ }^{32}$

Thirdly, there was the question of the agency of Van Heemskerk and the voc. At first sight, it seemed that this matter could easily be addressed by arguing that Van Heemskerk had acted as an agent of the Dutch Republic in its war against the Iberian monarchy. Whereas Grotius ultimately, in the final Chapter 13, resorted to this line of reasoning, the issue was not that simple or straightforward. At the time of the writing of De iure praedae, the international status of the young Republic of the United Provinces was as yet unsettled. For the Spanish government, the provinces which composed the Republic were rebels, even if on the ground they were often treated as lawful belligerents. ${ }^{33}$ Whereas the Republic had been able to sign alliance treaties with France and England, its international position remained unclear as long as the Spanish Monarchy had not ceded its claims. ${ }^{34}$

30 Grotius, IPC, viII, ff. $47-8$.

$31 \quad$ E.g. Richard Zouche, Iuris et Iudicii Fecialis, Sive, Iuris Inter Gentes, et Quaestionum de Eodem Explicatio (1650), ed. by Thomas Erskine Holland (The Classics of International Law; Washington: Carnegie Institute of Washington, 1911), I.6.2; Haggenmacher, 'Ancêtre', p. 10.

32 Grotius, IPC, IV, f. 5 o.

33 This also applied to the Santa Catarina case. The Portuguese governor of Malacca, Fernão de Albuquerque, expressly stated he did not claim the return of the Santa Catarina as it had been taken in a public war, implying it was a lawful prize, see Letter of 9 March 1603, in Grotius, Commentary, p. 524-5 (p. 524); Van Ittersum, Profit and Principle, p. 39. See Randall Lesaffer, 'Siege Warfare in the Early Modern Age: A Study on the Customary Laws of War', in The Nature of Customary Law: Legal, Historical and Philosophical Perspectives (Cambridge: Cambridge University Press, 2007), pp. 176-202, at pp. 179-80; Geoffrey Parker, 'Early Modern Europe', in The Laws of War. Constraints on Warfare in the Western World, ed. by Michael Howard, George J. Andreopoulos, and Mark R. Shulman (New Haven and London: Yale University Press, 1994), pp. 40-59, at pp. 48-50.

34 Beatrix C.M. Jacobs, 'The United Provinces: “Free” or "Free and Sovereign"?', in The Twelve Years Truce (16og). Peace, Truce, War and Law in the Low Countries at the Turn of the 17th Century, ed. by Randall Lesaffer (Leiden and Boston: Brill/Nijhoff, 2014), pp. 181-95. 
To circumvent this problem, Grotius made a major theoretical move. He resorted to the argument that under certain circumstances, private individualsor companies - had a right to wage war. For this he appealed to his theory of state formation and turned it on its head. According to Grotius, states were first established through social compacts. Under the social contract, the citizens had transferred all their natural rights to the state. Hence, states enjoyed exactly the same natural rights in their mutual relations as individuals had in the state of nature. Moreover, to them also accrued the duty to uphold and protect the rights of their citizens. The latter could no longer enforce their rights by themselves but had to appeal to the state's officials and judiciary to seek redress for the violation of their rights, whether by fellow citizens, other states, or foreigners. ${ }^{35}$ However, this did not completely exhaust their right to resort to force. In times and places where an appeal to the state was impossible, individuals could revert to private enforcement, including the use of force. The high seas, over which no state had or could hold jurisdiction, where the Santa Catarina had been captured, was such a place. There, the right to enforce their claims under natural law reverted to private individuals; in other words, there individuals benefited from the same rights and could resort to the same instruments of enforcement as states. They held a right to private just war, which differed in no way from public just war waged by the state. ${ }^{36}$

In the penultimate, twelfth chapter of his treatise, Grotius applied this circular theory to the case of the Santa Catarina. He reasoned that Van Heemskerk and co. had captured the Portuguese carrack in a private just war. Both for themselves and as agents of the voc, as well as on behalf of their local allies, they held sufficient just cause. Grotius sailed close to the justification and defence which Van Heemskerk had mounted in his correspondence with his employers, and which the court verdict had largely taken over. ${ }^{37} \mathrm{He}$ listed the excesses of violence, brutality, perfidy, and treachery, culminating in the unwarranted execution of seventeen Dutch sailors at Macao, with which the Portuguese harassed the merchants of the company and their local allies. To this he added the doctrinal argument that the Portuguese unjustified claim for an exclusive right to navigate and trade in the East Indies violated the natural right of communication and trade. ${ }^{38}$

\footnotetext{
35 Grotius, IPC, II, ff. 11-2'.

36 Grotius, IPC, viII, ff. $37-8$.

37 Report of the Broad Council of Van Heemskerk and his naval officers, 4 December 16o2, in Grotius, Commentary, pp. 531-2; Letter of Van Heemskerk to the Directors of the United Amsterdam Company of 27 August 1603, in Ibidem, pp. 533-45; Verdict of 9 September 1604. 
Within the general structure of the treatise, the argument that Van Heemskerk had acted in a private war was, however, only secondary to the author's main defence. In the final Chapter 13 of his massive brief, the young author made the case that Van Heemskerk had captured his prize in the context of a public war of the Dutch Republic, for which he had acted as an agent. Grotius could not claim that Van Heemskerk had acted under a privateering commission, as he was no holder of a letter of marque. This would have been most convenient as such commissions generally implied that the prize befell its captors, barring a portion for the state. If Van Heemskerk had however acted as a combatant under a state commission, the prize befell the state. ${ }^{39}$

Grotius had no choice but to fall back on the argument that Van Heemskerk had acted as a lawful combatant, similar to a soldier, acting for the state. For this, he referred to the edict by the Estates General of the United Provinces of 2 April 1599 whereby all trade with Spain was prohibited and all engaging in it - Dutch, third power subjects and by implication Spanish - were threatened with confiscation and capture of their ships and goods. ${ }^{40}$ This amounted to a wartime measure. As the capture of the Santa Catarina had occurred in a public war of state against state, it was immaterial to the enemy who had acted on behalf of the enemy state, and whether this person had done so under orders or not. This was a matter which held only relevance for the attribution of the prize - to the captor or the state -, and this was an internal matter for the captor's state to decide. ${ }^{41}$ However, Van Heemskerk had assuredly acted under orders of the Dutch Republic. For this Grotius could adduce two proofs. In first instance, the States of Holland, one of the sovereign provinces of the Republic, had warned the voc directors that they should prepare and arm to protect their trade, 'but also to take the initiative in making war upon the [Portuguese].42 Moreover, Van Heemskerk and some other captains held commissions from Prince Maurice of Nassau (1567-1625) in his capacity as admiral-general, which granted them the right to self-defence but also to 'seek reparation of injuries'. ${ }^{43}$ Grotius insisted that this did not constrain Van Heemskerk to seeking redress in proportion to damage and expenses, as there

39 Grewe, Epochs, p. 313.

40 Latin version in Hugo Grotius, De Jure Praedae Commentarius, ed. by H.G. Hamaker (The Hague: Martinus Nijhoff 1868), pp. 346-8; C.G. Roelofsen, 'Grotius and State Practice of his Day. Some Remarks on the Place of De Jure Belli ac Pacis within the Context of Seventeenth-Century 'Christendom' and the Role of Contemporary Precedents in Grotius' Work', Grotiana N.S. 10 (1989), 3-46, at pp. 20-1.

41 Grotius, IPC, XIII, ff. 137'-8.

42 Grotius, $I P C$, viII, f. 138.

43 Grotius, IPC, viII, f. 138', see Van Ittersum, Profit and Principle, p. 28. 
was also the right to inflict punitive damages. He further explained that such a commission allowed merchants to behave in exactly the same manner as naval officers. From this he drew the conclusion that Van Heemskerk and co. had taken a lawful prize in a public war in a capacity equal to that of a state official or soldier. As far as the Portuguese were concerned, this settled the matter for them. The internal division of the spoils fell under the jurisdiction of the Dutch admiralty courts. Probably realising that his reasoning was somewhat tortuous, the author brought a final argument to bear on the matter. For this he referred to reprisal, stating that it could not be supposed that an order to wage war - as in the edict of 1599 - was ever narrower than a letter of reprisal. By consequence, a captain acting like a state official, and whose behaviour was afterwards approved by the state, could never have less right to take from the enemy than a captain acting under a letter of reprisal - special or general. ${ }^{44}$

In the context of public war, Grotius made a striking implicit parallel with the institution of special reprisal in case of denial of justice. He drew a parallel between war and the enforcement of a judgment. Absent a supreme authority to turn to, states were left with no alternative than to appeal to the sovereign of the state which or whose subjects had violated their right or that of a subject. Grotius construed the procedure of declaring war in close parallel to a trial before a domestic court. The offended state had to make an appeal to the offending state to sit in judgment of their own and had expressly to make its case and stake its claim for redress. It was natural, according to Grotius, that the offending state would first be given the chance to render justice, as it represented the defence side in the process of the settlement of the dispute. If the offending state refused to render a verdict over its own or rendered a manifestly unjust ruling, then the plaintiff state had no choice but to render a judgment itself and execute it in a just war. ${ }^{45}$

This left Grotius, fourthly, with making the case why the prize befell its actual captors, Van Heemskerk and his men, and the voc. Inasmuch as they were private agents in a private war, they held a direct right to the prize, albeit limited under the rules of proportionality and punishment. This, however, was not a line of reasoning which would cut much wood in the internal debates among the Dutch elite. Inasmuch as the captors were public agents in a public war, the argument was easy. As the States of Holland had ceded any claim to the company and as the Amsterdam admiralty court had attributed the prize to the voc, Grotius could have been content here with invoking the general

\footnotetext{
44 Grotius, $I P C$, VIII, ff. 138'-9.

45 Grotius, IPC, viII, ff. 44'-6; Haggenmacher, Grotius, pp. 223-47.
} 
principle that under the law of nations it fell within the jurisdiction of the state to attribute prizes taken in war. ${ }^{46}$

This left, however, one knot for Grotius to tie to make his case fool-proof. Under the just war doctrine, wars opposed a just to an unjust belligerent. Only the just belligerent had a right to wage war and could thus gain title from wartime actions. All the belligerent actions on the side of the unjust party were ipso facto illegal. Because generally all belligerent states claimed to be the just belligerent and in the absence of any supreme earthly authority to turn to, it followed that it was virtually impossible to attain certainty about the lawfulness of a prize if the just war doctrine was taken to its consequences. This meant that any prize which was lawful in the eyes of one belligerent would be considered unlawful in the eyes of the other, and could lead to recapture or counter-reprisals. ${ }^{47}$

Grotius saw no way out of this quandary within the context of natural law. He could not lift the discriminatory logic of just war for those who acted under this law. These were private individuals in private war, and the states themselves in public war. He did, however, make an exception for individuals who acted under command of the state in public war. He appealed to a solution that some late-medieval canonists and theologians had already devised to shield soldiers and subjects from the consequences of participating in an unjust war under command of their prince. These authors had reasoned that because subjects were held to obey the commands of their rulers, they did not commit a sin if they participated in an unjust war, as long as the injustice was not manifest. They were considered to trust in good faith in the righteousness of their prince's command. ${ }^{48}$ The Spanish theologian Francisco de Vitoria (c. 1483-1546) had extended the benefit of this defence to princes themselves. ${ }^{49}$ Grotius applied a similar line of reasoning to subjects and soldiers with regard to prize-taking. He argued that as subjects were acting under the orders of the state, all their wartime actions were shielded by the authority of the state and thus had to be considered legal. Subjects were excused from the possible injustice of their ruler as they could believe in good faith that their orders were just inasmuch as the injustice was not manifest. Grotius claimed that it was customary for

46 Decree of the Estates of Holland of 1 September 1604, in Grotius, Commentary, pp. 515-6.

47 Oona A. Hathaway and Scott J. Shapiro, The Internationalists and Their Plan to Outlaw War (London: Allen Lane, 2017), pp. 23-7.

48 Gregory M. Reichberg, Thomas Aquinas on War and Peace (Cambridge: Cambridge University Press, 2017), pp. 223-56; Russell, Just War, p. 147.

49 Francisco de Vitoria, De iure belli 32, translation in Vitoria: Political Writings, ed. by Anthony Pagden and Jeremy Lawrance (Cambridge Texts in the History of Political Thought; Cambridge: Cambridge University Press, 1991), pp. 312-3. 
states to accept this and thus concede that prizes taken by subjects had to be deemed lawful. As this could have never been attained under the aegis of natural law, Grotius had to introduce a new category of law to imbed this custom in. At the inception of his treatise, the young author had reverted to the old distinction, which went back to Ulpian (d. 228), ${ }^{50}$ between primary natural law, which applied to all living beings, and secondary natural law, which applied to reasonable human beings alone and which Grotius also labelled the primary law of nations. ${ }^{51}$ From the latter he distinguished the secondary law of nations. In the more maturated exposition of the nova declaratio, a later addition to the manuscript of De Iure Praedae Grotius made in the years after 1606, he defined this as a law that exclusively applied to states and derived from the consent between states. ${ }^{52}$ In this manner, he secured the capture of the Santa Catarina from counterclaims based on the allegation that it had not been taken in a just public war.

\section{De Iure Belli ac Pacis}

Grotius never published his defence of the Santa Catarina's capture during his lifetime. The manuscript remained lost until its discovery in 1864. It was only fairly recently established to what extent Grotius had built on it for the fuller elaboration of his system of the laws of war and peace in his De iure belli ac pacis. ${ }^{53}$

De iure praedae did neither discuss reprisals - special or general - nor privateering. However, the legal theory of war that Grotius expounded in the treatise offered a framework that legitimised all key elements of these institutions. Grotius's defence of Van Heemkerk's action was paired against his virulent condemnation of the actions of the Portuguese as different forms of illegal robbery - piracy and other. As such, his work can be read as a legal exposition of what distinguished legal from illegal plunder. ${ }^{54}$

In his more mature systematisation of the laws of war and peace in the later treatise, Grotius likewise granted scant attention to reprisals. He devoted a brief chapter to the question of collective liability for subjects for the debts of

\footnotetext{
$50 \quad$ D. 1.1.1.3-4.

$51 \quad$ Grotius, IPC, II, ff. 5'-6'.

52 Grotius, IPC, II, f. 12; Haggenmacher, Grotius, pp. 331-99; idem, 'Génèse et signification du concept de "ius gentium" chez Grotius', Grotiana N.S. 2 (1981), 44-102.

53 The seminal study on this remains Haggenmacher, Grotius.

54 Michael Kempe, 'Beyond the Law. The Image of Piracy in the Legal Writings of Hugo Grotius', Grotiana N.S. 26-8 (2005-7), 379-95.
} 
their rulers, and therein referred to the practice of reprisal as an example and further elaborated on its regulations in a few short paragraphs..$^{55}$

All the dimensions of Grotius's theory of war from De iure praedae which gave legitimacy to reprisals and privateering returned in the later treatise. ${ }^{56}$ These were: the reconceptualisation of just war as a unilateral action to enforce subjective rights; the stretching of proportionality to its vanishing point; the idea of collective liability of citizens; and the duty for states to enforce their citizens' rights against other states and foreigners in case of denial of justice. To this list, De iure belli ac pacis added two more elements.

Firstly, Grotius added a second conception of war next to just war. Building on the concept of public war from the Digest ${ }^{57}$ and from late-medieval and sixteenth-century civilian jurisprudence, he introduced the concept of 'bellum solemne' (formal or regular war). ${ }^{58}$ This was a war fought between sovereign states - a public war - that had been formally declared. Its relevance was that such a war, whether it was just or unjust under natural law, was considered to be legal on both sides under the 'volitional' law of nations. It implied that both sides in the war held equal rights under the ius in bello and could thus gain legal title to conquests, plunder and ransom from belligerent action. ${ }^{59}$ Whereas Grotius had only made scant use of this category of human-made law of nations in De iure praedae, then under the name of secondary law of nations - to argue for the lawfulness of prize-taking by subjects regardless of the justice of the war on their side - , in his new treatise it was a major subject and was worked out into a full body of laws and regulations based on consent between states. ${ }^{60}$ Whereas just war was an institution of natural law, regular war was an institution of the manmade law that regulated the relations among states, which Grotius now simply labelled the law of nations. The conception of regular war served to extend the presumption of lawfulness from the acts of subjects to those of states themselves. This dualist reconceptualisation of just and regular war within the dual ambit of the law of nature and the law of nations was one of Grotius's major contributions to mainstream thought on international law from the late seventeenth to the midnineteenth century. ${ }^{61}$

55 Grotius, IBP, III.2, esp. 3.2.4.

56 Haggenmacher, Grotius, pp. 529-612.

57 D.49.15.24.

58 Haggenmacher, Grotius, pp. 284-8.

59 Grotius, IBP, III.3.4-5.

6o Grotius now classified collective liability as an institute of the law of nations, Grotius, IBP, III.2.2.

$61 \quad$ Randall Lesaffer, 'Aggression before Versailles', European Journal of International Law, 29 (2018), 773-8o8; Stephen C. Neff, Justice among Nations. A History of International Law (Cambridge, MA: Harvard University Press, 2014), pp. 158-66, 170-8 and 180-98. 
Secondly, Grotius's concept of formal, public war created a distinction between perfect and imperfect war. Whereas a perfect - or rather 'complete' (plenum) - war needed to be formally declared, an imperfect war was a clash between states which did not amount to full war because it had not been declared. ${ }^{62}$ Moreover, in defining war as a state rather than a series of belligerent actions, Grotius took a crucial step towards a legal separation of war from peace as two different periods to which different sets of law - the law of war and the law of peace - applied. Although this step would only be truly consummated during the nineteenth century, Grotius thereby opened the door to the reverse reasoning that belligerent actions by themselves did not trigger war and could thus occur in time of peace. This created a space for the institution of general reprisal during peacetime, and later for modern state-to-state reprisal as a measure short of war. ${ }^{63}$

\section{Conclusion}

With this, Grotius laid the final stone for the foundations of reprisals and privateering. His theory of just war as enforcement of subjective rights under the perspective of corrective justice legitimised the unilateral search for redress without regard for the general interest, which was the ultimate justification of special reprisal. His theory of social contract and the transfer of natural rights enforcement gave powerful support to the idea of collective liability and of the right of redress in case of denial of justice, the two major legal explanations for reprisals, whether special or general. His reading of proportionality and his theory of the right of punishment helped to overcome the gap between special and general reprisal. Finally, in De iure belli ac pacis, the Dutch humanist formed the basis for a theory of belligerent action during peace, and thus gave some ammunition to the proponents of general reprisals during peace.

Late-medieval scholars such as Bartolus had already framed special reprisals as a species of just war in order to overcome the moral and legal scruples against the principle of collective liability on which they were based. Grotius's reinterpretation of the just war doctrine gave additional ammunition to defend the by then extended practice of reprisal in its different legal appearances. His contribution did not end the controversy in legal literature about the desirability or justice of special reprisals, privateering in war, let alone of privateering in times of peace. Among the writers of the law of nature and of nations

\footnotetext{
62 Grotius, IBP, I.2.4.2 and III.3.5.

63 Neff, War and the Law of Nations, pp. 102, 119-30, and 215-49.
} 
of the later seventeenth and eighteenth centuries, voices were raised to warn against abuse and to attempt restricting them. ${ }^{64}$ For some writers who spoke in favour of reprisals, De iure belli ac pacis offered a powerful theory of justification they would gratefully refer to and which seemed to leave little need for additional argumentation. ${ }^{65}$ But more generally, as Grotius's novel interpretation of just war became foundational to the mainstream of the law of nature and of nations, it aided in having reprisals in their various forms to become quite generally accepted as a fact of international life in the literature of the late seventeenth and eighteenth centuries. ${ }^{66}$

64 Cornelius van Bynkershoek, Quaestionum Juris Public Libri Duo (1737), ed. by J. de Louter and Tenney Frank (The Classics of International Law; Oxford/London: Clarendon Press/ Humphrey Milford, 1930), I.24.

65 E.g. Zouche, Iuris et Iudicii Fecialis, I.6.2; Iohannes Baltasar Wernherus and Johannes Georg Conrad, De Iure Repressalairum inter Principes Imperii (Wittenbergae: prelo Viduae Gerdesianae, 1715), pp. 8-9; Domenico Alberto Azuni, The Maritime Law of Europe, vol. II (New York; I. Riley \& Co., 1806), p. 339.

66 Christian Wolff, Jus Gentium Methodo Scientifica Pertractatum (1749, 1764), ed. by Otfried Nippold and Joseph H. Drake (The Classics of International Law; Oxford/London: Clarendon Press/Humphrey Milford, 1934), V.589-6o6; Emer de Vattel, Le Droit des Gens, ou Principes de la Loi Naturelle (1758), ed. by Albert de La Pradelle and Charles G. Fenwick (The Classics of International Law; Washington: Carnegie Institution of Washington, 1916), III.18, pp. 342-54; Martens, Essay on Privateers. 